\title{
Imperfective Aspect and the Interplay of Aspect, Tense, and Modality in Torau
}

\author{
Bill Palmer
}

\author{
UNIVERSITY OF SURREY
}

\begin{abstract}
Torau displays a highly complex system of aspect, tense, and modal marking. One of the most complex elements of this system is the marking of imperfective aspect. Imperfective in Torau is marked by a construction employing a choice of two overt imperfective markers and the possible presence of reduplication. The range of imperfective semantics encoded by this construction varies widely, encompassing progressive, habitual, persistive, and progressive inchoative or inceptive. Which reading is given depends not only on the choice of imperfective marker and the presence or absence of reduplication, but on a complex interplay of these factors with other aspectual, modal, or tense marking, and the aspectual semantics of the verb itself. This paper teases apart each of these highly interdependent factors to determine the independent functional characteristics of each imperfective marker and of reduplication.
\end{abstract}

1. THE IMPERFECTIVE CONSTRUCTION IN TORAU. ${ }^{1}$ Torau is a member of the Northwest Solomonic (NWS) subgroup of Western Oceanic, one of three languages within the Mono-Uruavan subgroup of NWS that also includes Mono-Alu and the now extinct Uruava (Ross I988:2 I5). Torau is spoken by about I,200 individuals in three villages on the east coast of Bougainville: Vito, Tarara, and Rorovana (with its subvillages Amata Geesi 'Big Village', also known as Rorovana I, and Sivilnai or Rorovana 2).

Torau marks imperfective aspect using a construction unique to NWS (Ross I982, Palmer to appear). In this construction, found in all NWS first-order subgroups except Choiseul, postverbal particles or enclitics index one of the core arguments, typically the nominative subject (i.e., the A or S). Across NWS this construction assigns a particular aspectual status to the clause, typically imperfective, or some subtype of imperfective such as continuous, progressive, or durative. The morphology carrying this function is either identical to that used in adnominal indirect possessor-indexing constructions in that language, or is historically derived from former possessor-indexing morphology.

I. The support of UK Arts and Humanities Research Council grant APNI9365 in the preparation of this paper is gratefully acknowledged. All Torau data was collected by the author in the field on field trips funded by the same grant. An earlier version of this material was presented at a Surrey Morphology Group features workshop on aspect in May 2007. I am grateful to participants at that workshop for their comments, and for the comments of two anonymous reviewers. All errors remain mine. 
In Torau these aspect-marking subject-indexing forms have formally diverged from adnominal possessor-indexing forms and have no synchronic identity with their cognate adnominal forms. ${ }^{2}$ They assign to the clause the aspectual status of imperfective, the semantics of which is discussed in section 4 below.

These imperfective-markers are not affixes. They follow the rightmost element in a syntactic structure larger than the word, whether that element is a verb, an adverb, or an object enclitic, as in (7). However, they are prosodically deficient and combine with the preceding form to constitute a single Prosodic Word, and are thus not independent words. They are therefore Phonological Clitics (Anderson 2005:23).

These enclitics are morphologically complex, at odds with claims that clitics must be morphologically simplex (Inkelas I990:24I). Two distinct forms, $(i) s a$ - and $e$-, mark imperfective aspect. They also function morphologically as host for postverbal subjectindexing suffixes. Two paradigms of subject-indexing imperfective markers therefore occur, shown in tables I and 2.

The parenthesized vowel in table I indicates that the form of this enclitic is either isaor $s a$-. There appears to be no functional distinction between the two, with some speakers tending to use $i s a$ - more than other speakers, and an opinion reported by some speakers that the form isa-is more correct. In addition, some verbs, such as postural verbs, appear to be more likely to display the isa-form, but both forms occur with all verbs, and informants accept both and claim no semantic distinction. $\mathrm{Sa}$ - occurs with much higher frequency than $i s a$ - in unelicited data, so this marker will henceforth be presented simply as sa-.

The subject-indexing function of the enclitics in tables I and 2 is straightforward: in each paradigm an identical set of suffixes attaches to a host form to index arguments representing the expected person and number categories. The argument indexed is always the nominative subject, that is, the $\mathrm{S}$ of an intransitive predicate or the A of a transitive one. What is less transparent is the function of the two indexing hosts $s a$ - and $e$-. Both assign an ongoing status to the event expressed by the predicate: ${ }^{3}$

\section{TABLE 1. IMPERFECTIVE ASPECT SUBJECT-INDEXING ENCLITICS WITH $(i) s a-$}

$\begin{array}{lcccc} & \text { IEXCL } & \text { IINCL } & 2 & 3 \\ \text { SG } & \text { (i)sa-gu } & - & \text { (i)sa-u } & \text { (i)sa-la } \\ \text { PL } & \text { (i)sa-mani } & \text { (i)sa-da } & \text { (i)sa-mu } & \text { (i)sa-dia }\end{array}$

\section{TABLE 2. IMPERFECTIVE ASPECT SUBJECT-INDEXING ENCLITICS WITH $e$ -}

$\begin{array}{ccccc} & \text { IEXCL } & \text { IINCL } & 2 & 3 \\ \text { SG } & \text { e-gu } & - & \text { e-u } & \text { e-la } \\ \text { PL } & \text { e-mani } & \text { e-da } & \text { e-mu } & \text { e-dia }\end{array}$

2. They are, however, formally identical to a series of possessive pronouns with meanings such as 'mine'. Nonetheless, informants' responses indicate that speakers regard these forms as homophonous with and functionally unrelated to the subject-indexing forms.

3. Examples conform to the Leipzig Glossing Rules, except for RL, realis; person, number, and grammatical relations combinations, which are glossed together (e.g., 3SGS for third singular subject); and " $\approx$ ", which indicates that the reduplicant is a clitic (see 3.2). 
(I) a. Pita ma-to geesi=sa-la.

Peter RL.3SGS-PST be.big=IPFV-3SGS

'Peter was big.'

b. Pita ma-to $\mathbf{s o 0} \approx$ sobii=e-la.

Peter RL.3SGS-PST RD $\approx$ walk=IPFV-3SGS

'Peter was walking.'

Moreover, reduplication plays a part in imperfective marking. Reduplication in Torau falls into two types: functionally and formally unpredictable derivational reduplication, and regular apparently exceptionless inflectional reduplication with a specific distinct phonological structure (discussed in section 3 below). Reduplication with this form occurs in exactly two morphosyntactic contexts: clauses negated by the clitic $k a$, and the imperfective construction with postverbal subject-indexing. However, not all clauses displaying postverbal imperfective marking also display reduplication, as (Ia) shows. Instead, reduplication always cooccurs with the imperfective marker $e$-, while the marker $s a$-typically occurs without it. An examination of unelicted texts reveals a strong association between reduplication, the marker $e^{-}$, and active verbs; and a strong association between absence of reduplication, the marker $s a$-, and stative verbs. This allows a preliminary hypothesis that:

(2) a. sa- encodes stative imperfective;

b. $e$-encodes active imperfective; and

c. reduplication iconically marks active verbs as referring to multiple occurrences of an active event.

This is supported by the behavior of imperfective marking with verbs whose semantics plausibly allow stative or active readings. In (3a) $s a$-and the absence of reduplication give the clause a stative reading, causing mate to refer to an ongoing state of being dead, while in ( $3 \mathrm{~b}) e$ - and reduplication combine to give the clause an active reading, causing the verb to refer to an ongoing inchoative process of dying.

(3) a. Pita ma-to mate=sa-la.

Peter RL.3SGS-PST be.dead=IPFV-3SGS

'Peter was dead.'

b. Pita ma-to $\mathbf{m a a} \approx$ mate $=\mathbf{e}-\mathbf{l a}$.

Peter RL.3SGS-PST RD $\approx$ be.dead=IPFV-3SGS

'Peter was dying.'

However, closer examination of the corpus, accompanied by elicitation and the testing of combinations in the field, reveals a much more complex picture: verbs of all semantic types, indeed perhaps all verbs in the language, may occur with each of the combinations expressed in (4) and illustrated in (5).

(4) a. $e$-with reduplication

b. $s a$ - with no reduplication

c. $s a$ - with reduplication

(5) a. Pita ma-to gee $\approx$ geesi=e-la.

Peter RL.3SGS-PST RD $\approx$ be.big=IPFV-3SGS

'Peter was becoming big.' 


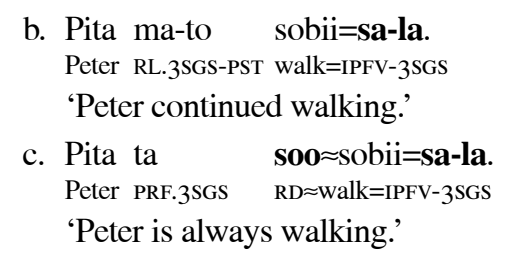

The only combination that does not occur in the corpus and is not accepted by speakers for any verb is $e$ - without reduplication. Moreover, the reading given to each combination of $s a-, e-$, and reduplication varies widely, depending on the combination of other aspect, tense, and modal markers present in the clause, along with the aspectual semantics of the verb. This raises two key questions relating to the expression of imperfective aspect in Torau:

(6) a. what determines the choice of $s a$ - and $e$-? and

b. what role does reduplication play?

This paper attempts to answer these questions.

\section{ASPECT, MODALITY, AND TENSE IN THE TORAU VERB COMPLEX.}

To understand the role of reduplication and the two imperfective markers, it is necessary to place these in the context of the overall modal, aspectual, and tense marking in the language.

Torau, like the two other Mono-Uruavan languages, has a verb-final structure in pragmatically unmarked clauses, and displays other right-headed phenomena such as postpositions (Ross I988:253-55). However, Torau retains traces of an earlier left-head typology, including several functionally restricted prepositions and postnominal lexical modifiers.

As in many Oceanic languages, the Torau main verb may be accompanied by a suite of grammatical forms including particles and clitics, along with certain adverbs, serialized verbs, and incorporated nouns. Many of the grammatical particles express aspectual, modal, and tense categories. As is true elsewhere in Oceanic, these various forms comprise a poorly defined syntactic unit referred to as the verb complex. The place of reduplication and imperfective marking in the Torau verb complex, along with the formal and functional characteristics of other aspectual, modal, and tense markers that interact with the imperfective, is described in this section.

The overall syntactic structure of the Torau verb complex is as follows:

(7) $\mathrm{TAM} / \mathrm{SBJ}([=] \mathrm{NEG})(=\mathrm{DIRAUX})(\mathrm{RD} \approx)(\mathrm{ADV} \mathrm{I})$

$$
(\mathrm{ADV} 2 *)(=[\text { APPL- }] \mathrm{OBJ})(=\mathrm{IPFV} / \mathrm{SBJ})(=\mathrm{DIRI})([=] \mathrm{TA})(=\mathrm{DIR} 2)
$$

The first line of (7) represents the sequential order of forms that precede the verb in the verb complex, while the third line represents the order of forms that follow the verb.

Negation is marked by a form $k a$ that encliticizes to the preceding TAM/SBJ particle if one is present; if no such particle is present, negation is marked by the independent particle $a k a$. DIRAUX are cliticized reduced forms of deictic verbs (=la corresponding to the free verb lao 'go' and =lama corresponding to the synchronically monomorphemic free verb lauma 'come'). The elements DIRI and DIR2 are deictic directional markers. These 
various directional forms are not discussed further here. Each other element in (7) marks or interacts with aspect and is outlined in more detail below. The most important of these is TAM/SBJ, a morphologically complex preposed particle that carries subject-indexing, marking for modality or perfect aspect, and past tense marking if present, each of which is discussed separately in $2 . \mathrm{I}-2.3$ below.

2.1 MODALITY. All finite clauses in Torau have some modal status, either realis or irrealis, regardless of whether overt modal marking is present. Modality is marked overtly by preverbal particles that also index the nominative subject, shown in tables 3 and $4{ }^{4}$

The Torau system represents a functionally neat exemplar of the prototypical modal distinction between realis (as specific real events) and irrealis (as events that are not specific real events). Realis clauses refer to events located in the past, ranging from the distant past as in (8a), to the very recent past in (8b), and to those located at the moment of speaking as in (8c). Clauses marked with the realis series and no other TAM markers or temporal adverbials depend on discourse context to disambiguate past events from present events.

(8) a. Elai ma=lama kaisi=a pidani.

DEM RL.3SGS=come take $=3$ SGO land

'She came and bought the land [ I50 years before].'

THo73

b. Elai Buini ma-da-to kaa $\approx k a d e k i=a=e-d a$.

DEM Buin RL-IINCLS-PST RD $\approx$ tell.story $=3 S \mathrm{SGO}=I P F V-I I N C L S$

'We were talking about Buin [just a moment ago].'

WWIII 28

c. Itola $=\mathrm{i}$ ma-da agisi=to.

there $=$ LOC RL-IINCLS be.near-PRS

'We are almost there.'

OLo83

The irrealis clauses refer to events that are not specific real events (i) because they are located in the future, and have therefore not happened and are not real, as in the second clause of (9a); (ii) because they are hypothetical, as in (9b); or (iii) because they are past counterfactuals, as in $(9 \mathrm{c}, \mathrm{d})$. They also refer to events that are not specific real events because they are habitual, either present, as in the first clause of (9a), or past, as in (9e).

\section{TABLE 3. REALIS PREVERBAL SUBJECT-INDEXING PARTICLES}

\begin{tabular}{|c|c|c|c|c|}
\hline & IEXCL & IINCL & 2 & 3 \\
\hline SG & ma-gu & - & \multirow{2}{*}{$\mathrm{mu}$} & $\mathrm{ma}$ \\
\hline PL & mani & ma-da & & $\mathrm{di}$ \\
\hline
\end{tabular}

TABLE 4. IRREALIS PREVERBAL SUBJECT-INDEXING PARTICLES

\begin{tabular}{|c|c|c|c|c|}
\hline & IEXCL & IINCL & 2 & 3 \\
\hline SG & $\mathrm{kae}$ & - & \multirow{2}{*}{ pa } & pae \\
\hline PL & mani-pa & da-pa & & di-pa \\
\hline
\end{tabular}

4. The IEXCLSG and 3 SG portmanteau forms in table 4 often occur with the phonologically reduced forms $k a$ and $p e$ respectively. 
(9) a. ine pa waa $\approx w a=i n-a u=e-u \quad$ "pa kai=au"

you.SG 2 S.IRR $R D \approx S a y=A P P L-I S G O=I P F V-2 S G S$ 2S.IRR carry=ISGO

'... you're always saying to me "you carry me". $\quad$ TS2O2-202A

b. Atee ta-pae dako=a elai pe rausu.

water PRF-3SGS.IRR encounter $=3$ SGO that 3 SGS.IRR be.finished

'If water touches him he'll be finished.' TS I80-I80A

c. Ela da-pa=ka ua=ai, elai itoio da-pa tuu=isa-da.

that IINCLS-IRR $=$ NEG say $=3$ SGO that there IINCLS-IRR stay=IPFV-IINCLS

If we didn't do that [fight], we would still be there.'

THo6I

d. Baina pe $=k a \quad a-a r a p=i a$.

woman 3 SGS.IRR $=$ NEG $\quad$ CS-go.across $=3$ SGO

'The woman didn't carry him across.'

TS200B

e. Nimani lagoo asa omano atunu ialata-mani-palao-ou=ma ...

we.EXCL subsequently only like smite fishPRF-I EXCLS-IRRgo-descend=hither

mani-pa papagi, mani-pa lao-sae abani.

IEXCLS-IRR search IEXCLS-IRR go-ascend return

'After that only to catch fish would we come down ... we would search and we would go back up.'

WWIII 43-I46

Irrealis clauses may display the present tense marker to, indicating that the event is about to happen immediately:

$\begin{array}{ll}\text { (IO) a. Da-pa=lo } & \text { matate=to. } \\ \text { IINCLS-IRR=go } & \text { emerge-PRS }\end{array}$

'We are about to arrive.'

OLo85A

b. Elai kae dopisa $=$ in- $a=l a=$ to atee.

that ISGS.IRR release $=$ APPL-3SGO=thither=PRS water

'I'm releasing the water now.'

MMo49

Realis is the default modal status. In most morphosyntactic contexts it is not overtly marked, and the realis series given in table 3 does not occur. Overt realis marking only occurs when it is required to provide a morphosyntactic locus for other marking, in the form of preverbal subject-indexing or the past tense marker -to. Both these features are expressed by bound (or portmanteau) forms requiring a preverbal host. The perfect aspect marker $t a$ (discussed in 2.2 below) also functions as the morphosyntactic locus for subject-indexing and past marking, so overt realis marking is unnecessary when perfect marking is present and they do not cooccur. In the absence of perfect marking, overt realis marking occurs when the past tense marker is present, as it requires a host. In the absence of perfect and past marking, overt realis marking occurs when no postverbal subject-indexing is present, and realis marking is therefore the only possible locus for subject-indexing. When postverbal subject-indexing is present, preverbal subject-indexing is redundant, and it and the realis marker hosting it do not occur (unless required to host past marking). In a nutshell, overt realis marking is ungrammatical:

( I I) a. in clauses carrying perfect marking; or

b. in clauses carrying postverbal subject-indexing, unless the past marker is present.

Overt irrealis marking may be omitted in imperative and hortative clauses. 
2.2 PERFECT ASPECT. Perfect aspect in Torau, using the preverbal particle $t a$, marks the clause as expressing a prior event with continuing relevance. As with modal marking, this also functions as host for preverbal subject-indexing. This particle carries a set of subject-indexing suffixes that partially correspond to those occurring with the realis marker in table 3 . In irrealis clauses, these are further suffixed with the irrealis marker $p a$, also seen in table 4, with the exception of the ISG and 3SG categories, where the entire portmanteau forms employed in nonperfect irrealis are suffixed to $t a$. The paradigm unmarked for irrealis is by default realis and is shown in table 5 , while the perfect irrealis paradigm is given in table 6 .

In realis clauses, perfect aspect marks the event as occurring in the recent past with continuing relevance in the present, as in (I2a), or occurring in an earlier time with continuing relevance at some point in the past already established in the discourse, as in (I2b). In (I2a) the speaker is suffering the effects of having to wade across a river rather than be carried by the addressee. The relevance of the past event is therefore felt at the moment of speaking (hence the interpretation of perfect as a marker of recent past). In (I2b) the narrative has established an earlier time (in this case WWII) as the temporal locus of the events. Clause I therefore refers to an event that occurred and then had continuing relevance as the context for the past event expressed by the subsequent clause.

$\begin{array}{lll}\text { (I2) a. Ta-u uara=in-au .... } & \text { Ta-u=ka } & \text { kaa } \approx \text { kai=au. } \\ \text { PRF-2SGS be.unwilling=APPL-ISGO } & \text { PRF-2SGS=NEG } & \text { RD } \approx \text { arry=ISGO }\end{array}$ 'You have been lazy toward me .... You haven't carried me.'

TS205-2I2

b. Yamamoto ta lauma elai itaa Buini di=lama atun=a. Yamamoto PRF.3SGS come that here Buin RL.3PLS=come smite $=3$ SGO 'Yamamoto had come [and] they [Americans] came and killed him here at Buin.'

WWIII 5

These readings may be reinforced by the presence of overt tense marking. The clause in (I3a) is marked for present tense, indicating that the event is occurring at the moment of speaking, but is also marked for perfect aspect, indicating that it occurred prior to that moment. These combine to give the reading that the event is the continuation in the present of an event already occurring prior to the moment of speaking. In (I3b) overt past tense marking indicates that the event had occurred prior to a past location in time already established in the discourse.

TABLE 5. PERFECT PREVERBAL SUBJECT-INDEXING PARTICLES (DEFAULT REALIS)

SG

$\begin{array}{cccc}\text { IEXCL } & \text { IINCL } & 2 & 3 \\ \text { ta-gu } & - & \text { ta-u } & \text { ta } \\ \text { ta-mani } & \text { ta-da } & \text { ta-mu } & \text { ta-di }\end{array}$

TABLE 6. PERFECT PREVERBAL IRREALIS SUBJECT-INDEXING PARTICLES

$\begin{array}{ccccc} & \text { IEXCL } & \text { IINCL } & 2 & 3 \\ \text { SG } & \text { ta-kae } & - & \text { ta-u-pa } & \text { ta-pae } \\ \text { PL } & \text { ta-mani-pa } & \text { ta-da-pa } & \text { ta-mu-pa } & \text { ta-di-pa }\end{array}$


(I3) a. Kuresu (ta) u u $\approx$ uaka=e-la=to.

Kuresu PRF.3SGS RD $\approx$ work=IPFV-3SGS=PRS

'Kuresu is (still) working.'

b. Dosiro itaa ta-di-to tuu=sa-dia.

Dosiro here PRF-RL.3PLS-PST sit=IPFV-3PLS

'The Dosiro were already here.'

THoor9

In irrealis clauses, perfect aspect marks the clause as referring to a future or hypothetical event that will have continuing relevance at some time in the future, or to habitual events prior to an established time, with continuing relevance at that time. In (I4a), perfect marking indicates that clauses I and 2 express events that have not yet occurred, but which if they do occur will have continuing relevance as the context for the event expressed by the subsequent clause 3. In (I b b), the clause refers to habitual events located in the past that were prior to and had continuing relevance for subsequent past events expressed by the next clause as the context that would give rise to those subsequent events.

(I4) a. Itaa amata=i ta-mu-pa tuu=sa-mu,

here village $=$ LOC PRF-2PLS-IRR sit $=$ IPFV-2PLS

Siapani ta-mani-pa $=$ lo $\quad$ bomu $=$ ai,

Japan PRF-IEXCLS-IRR $=$ go $\quad$ bomb $=3$ SGO

nimu mani-pa atunu ari-atapo- $\mathrm{i}=\mathrm{mu}$.

you.PL IEXCLS-IRR smite RECIP-be.together-TR=2PLO

'If you stay here in the village, if we bomb the Japanese we will kill you all together.'

WWIII37-I39

b. Sikuna ta-di-pa laa $\approx \mathrm{lao}=\mathrm{e}-\mathrm{dia}=\mathrm{ma} \quad$ boni=ai.

ship PRF-3PLS-IRR RD $\approx$ gO=IPFV-3PLS=hither night=LOC

Ine pa bola=sa-u.

you.SG 2SGS.IRR hear=IPFV-2SGS

'Ships would go in the night. You would hear [them].' WWII $187-188$

This coding of events as hypothetical, habitual, or future, but with continuing relevance as the context for subsequent events, gives clauses marked with perfect and irrealis a conditional reading. This is the only way the conditional function is expressed in Torau, the language lacking any other construction or formal marker to express conditionality.

2.3 PAST TENSE AND DEFINITE IRREALIS MODALITY. The preverbal modal/aspectual subject-indexing particle may also display a suffix -to. This is a bound form that requires a preverbal particle as host. The marker has two distinct functions that are on the face of it difficult to reconcile semantically, one occurring in realis clauses, the other in irrealis clauses.

In realis clauses, -to locates the referent event wholly in the past, as in (I $5 \mathrm{a}$ ), in contrast with events located in the past that may or may not still be occurring, as in (I5b).

(I5) a. Italai di-to tuu=sa-dia.

there RL.3PLS-PST Sit=IPFV-3PLS

'They were sitting there (but no longer are).'

TSio3B

$\begin{array}{ll}\text { b. Italai } & \text { tuu=sa-dia. } \\ \text { there } & \text { sit=IPFV-3PLS }\end{array}$

'They were sitting there (and may or may not still be).' 
In addition to simply locating events in the past, -to gives an additional durative aspectual sense to the clause. With stative or postural verbs it indicates that the event occurred over a period of time in the past. In (I5a) the clause is marked as imperfective, and so refers to an ongoing event in any case. In (I6a), however, no imperfective marking is present. Here -to gives the clause a reading in which the event occurred over a longer period in the past than the corresponding clause without to in (I6b). This gives (I6a) the durative reading of 'live' as opposed to 'sit' in ( $\mathrm{I} 6 \mathrm{~b})$ :

(I6) a. Italai di-to tuu.

there RL.3PLS-PST sit

'They used to live there (but no longer do).'

TSIO3B

$\begin{array}{ll}\text { b. Italai di tuu. } & \text { dit } \\ \text { there RL.3SGS } & \text { sit }\end{array}$

'They were there/were sitting there (and may or may not still be).'

In realis clauses expressing punctual events, -to indicates that the action occurred in the past and is no longer occurring, but with an additional durative sense giving the clause a habitual reading, as in (17a). Without -to the clause lacks the habitual reading:
a. Tolou di-to ani=dia.
eel RL.3PLS-PST eat=3PLO
'They used to eat eels (but no longer do).'
b. Tolou di ani=dia.
eel RL.3PLS eat $=3$ PLO
'They ate eels (and may or may not still do so).'

In realis clauses expressing punctual events, where a temporal adverb precluding a habitual reading is also present, -to again indicates that the event occurred in the past and is no longer occurring, but here -to gives an iterative rather than strictly durative reading, indicating that the event occurred on more than one occasion, as in (I8a). Without -to the clause indicates that the event occurred on one occasion only, as in ( $18 b$ ):

(I8) a. Aniani lagoo di-to tere=dia.

food subsequently 3 PLS-PST give $=3$ PLO

'Later they gave food (on several occasions).'

WWIII07

b. Aniani lagoo di tere $=$ dia.

food subsequently 3 PLS give $=3$ PLO

'Later they gave food (on one occasion).'

However, -to cannot be interpreted as simply encoding past habitual, as it occurs in contexts in which the event cannot be habitual. The durative rather than habitual reading of realis with -to can be seen in (I9), where the blood is flowing on a single occasion, but over an extended period of time:

(I9) Asi-na elai masi-na ma-to a ale geesi=e-la. younger.sibling-3SGP that blood-3SGP RL.3SGS-PST RD $\approx$ flow be.big=IPFV-3SGS

'His little brother's blood was flowing strongly.'

TSo45A

In negative realis clauses, -to gives a slightly different reading. It again locates the event, or rather its nonoccurrence, wholly in the past, but it further indicates that this nonoccurrence was contrary to expectations: 
(20) Elai sikuna di-to=ka laa $\approx$ lauma.

DEM ship RL.3PLS-PST=NEG RD $\approx$ come

'The ships didn't come (after all).'

WWII050

Past marking with -to is not obligatory in clauses expressing events prior to the moment of speaking, as realis clauses may be interpreted as referring to past or present events depending on context. Instead, -to is used when the speaker wishes to make it clear that the events occurred wholly in the past:

In irrealis clauses, -to has a somewhat different semantic effect. Instead of locating the event in the past, it combines with irrealis marking to give a definite irrealis reading. In this context it has a modal function indicating that the speaker regards the event as definitely going to occur, or that the subject is under an obligation to carry out the event. In clauses referring to future events, it may indicate that the speaker regards the subject as under an obligation to carry out the event:

$$
\begin{aligned}
& \begin{array}{llll}
\text { Inau } & \text { Ipiu=ai } & \text { kae-to } & \mathrm{u} \approx u a k a=e-g u \\
\text { I } & \text { Ipiu=LOC } & \text { ISGS.IRR-DEFIRR } & \mathrm{RD} \approx \text { work=IPFV-ISG }
\end{array} \\
& \text { 'I have to continue working for Ipiu.' }
\end{aligned}
$$

With second person subjects this may give the clause imperative illocutionary force, indicating that the speaker regards the addressee as obliged to carry out the event, as in clauses I and 3 in (22).

$\begin{array}{lll}\text { Pa-to lukautu atoro=in-a=e-la. ... } & \text { Ta-pae-to } \\ \text { 3SGS.IRR-DEFIRR look.after be.good=APPL-3SGO=SBJ-3SGS } & \text { PRF-3SGS.IRR-DEFIRR }\end{array}$

$$
\begin{array}{llll}
\text { ua=in-o } & \text { "e alo=in-au," } & \text { pa-to } & \text { alo=in-a. } \\
\text { say=APPL-2SGO } & \text { oh do=APPL-ISGO } & \text { 2S.IRR-DEFIRR } & \text { do=APPL-3SGO }
\end{array}
$$

'You must look after him well. ... When he says to you "do this for me," you must do it for him.'

Alternatively, when combined with perfective aspect in future events, -to indicates that the speaker believes the event will definitely occur, as in the second clause in (22). Such clauses have the reading 'when' the event occurs, as in (23a), in contrast with corresponding clauses without -to, which have the less definite reading of 'if' the event occurs, as in (23b):

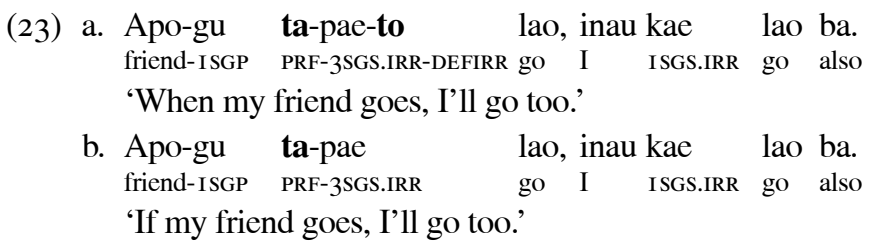

When referring to habitual events, -to again indicates that the subject is obliged to carry out the action, as in clause I of (24), or that the subject has a right to carry out the action, as in clause 3 of (24):

$\begin{array}{llll}\text { (24) Itaa nida sa-da abani da-pa-to } & \text { an=a. } \\ \text { here we.INCL } & \text { Poss-IINCLP } & \text { own IINCLS-IRR-DEFIRR } & \text { eat=3SGO }\end{array}$
Anua ta-di-pa-to
peko=ia, di-pa-to=lama
kais=ia.

people PRF-3PLS-IRR-DEFIRR like $=3$ SGO 3 PLS-IRR-DEFIRR $=$ come take $=3$ SGO

'Here we have to eat our own [food]. When other people want it, they can come and take it.'

STo30-03IA 
It is not immediately apparent how the two broad realis and irrealis sets of functions of -to are to be reconciled. However, given that -to in realis clauses and -to in irrealis clauses are formally identical, are in complementary distribution, and have identical morphosyntactic behavior aside from their attachment to realis and irrealis particles, respectively, it may be hypothesized that they are instances of a single morpheme, and that their functions may be reconciled on further investigation.

2.4 PREVERBAL ADVERBS. A preverbal position (ADVI in [7]) exists within the verb complex for syntactically and phonologically independent adverbial particles expressing various aspectual or temporal categories. These are not serialized verbs, as they cannot occur without a following main verb. They include:

(25) boo 'previously'

mala 'to a small extent (a little bit, for a little while)'

aru 'always'

ago 'just now (just a moment ago, in just a moment)'

This position is confined to these particles, and clause level temporal adverbs and adjuncts may not occur here.

2.5 POSTVERBAL ADVERBS. Several postverbal adverb positions (ADV2* in [7]) exist within the verb complex. These may be occupied by a range of adverbs that only occur within the verb complex in one or other of these positions and express various manner and aspectual categories. These are not serialized verbs, as they cannot occur without a preceding main verb. They include:

\begin{tabular}{|c|c|c|}
\hline (26) & sakesake & ‘quickly' \\
\hline & bebela $\sim$ bela & 'quickly, easily' \\
\hline & atikiai & ‘slowly, softly' \\
\hline & lee & 'immediately' \\
\hline & ai & 'initially' \\
\hline & $\begin{array}{l}\text { uua uuai } \\
\text { taolo } \sim \text { taon- }\end{array}$ & $\begin{array}{l}\text { 'in that direction' } \\
\text { 'again' }\end{array}$ \\
\hline
\end{tabular}

2.6 POSTVERBAL TENSE/ASPECT. A syntactic position close to the right margin of the verb complex (TA in [7)] may be occupied by one of two tense/aspect markers:

(27) =to 'present tense'

gito 'completive aspect'

The form to is an enclitic marking present tense (not to be confused with the past tense/definite irrrealis suffix -to discussed in 2.3 , which occurs in a different location in the verb complex). However, present to is not obligatory in clauses expressing events occurring at the moment of speaking, as realis clauses may be interpreted as referring to past or present events, depending on context. Instead, to is used when the speaker wishes to make it clear that the events are occurring right at the moment of speaking:

$$
\begin{aligned}
& \text { (28) Na tabi ... ta taa } \approx \text { tanisi=e-la=ma=to. } \\
& \text { SG child PRF.3SGS } \quad \text { RD } \approx \text { cry=IPFV-3SGS=hither=PRS } \\
& \text { 'A child ... is coming crying (right now).' }
\end{aligned}
$$


In addition to marking present tense, to carries an evidential component, in that a clause may only be marked with to if the speaker can actually see or hear the event occurring as they speak:

(29) a. Laa $\approx$ lauma $=\mathrm{e}-\mathrm{dia}=\mathbf{t o}$.

RDCOMe $=$ IPFV-3PLS=PRS

'They are coming now.' (I can see them.)

b. $E \approx e r a=e-d i a=t o$.

$R D \approx$ Sing $=I P F V-3$ PLS $=P R S$

'They are singing now.' (I can hear them.)

Although typically occurring in realis clauses, to may cooccur with irrealis marking to indicate that the event is about to happen immediately, as discussed above and exemplified in (IO), and that the speaker can hear or see that it is about to happen.

The form gito occurs as a phonologically independent particle in the same syntactic position as present to, and marks the event as complete at the time referred to: plane RL.3SGS go COMPL
'The plane has already gone.'
b. Balusu ta lao gito.
plane PRF.3SGS go COMPL
'The plane had already gone.'

\section{REDUPLICATION}

\subsection{PHONOLOGICAL CHARACTERISTICS OF TORAU INFLECTIONAL} REDUPLICATION. Derivational reduplication in Torau is phonologically unpredictable, involving either a CV reduplicant copying an initial syllable, or disyllabic copying of an entire initial foot. In contrast, inflectional reduplication is entirely regular. Only the initial mora of the base is copied, accompanied by any preceding onset consonant present. This copied single mora then lengthens to generate a complete bimoraic foot with the melody of the copied vowel. This occurs even when the initial syllable of the base is bimoraic, as shown in (29a) and in clause 2 of (I2a) above, where only the melody of the first $\mathrm{V}$ of the diphthong is copied but then lengthens. However, where the copied mora of the base is not preceded by an onset consonant, and the reduplicant vowel is therefore immediately adjacent to the base vowel with its identical melody, lengthening does not occur, as in (29b) above and (3ra) below. A more detailed discussion of the phonology of Torau reduplication is beyond the scope of this paper.

\subsection{MORPHOSYNTACTIC CHARACTERISTICS OF INFLECTIONAL}

REDUPLICATION. The inflectional reduplicant is not a prefix but a proclitic. Evidence from the presence of preverbal adverbial particles (discussed in 2.4 above) shows reduplication applying to the first syntactic word following the preverbal TAM/SBJ particle. This may mean that the verb stem itself provides the base for reduplication, as in (3Ia) and (32a). However, if one of the preverbal adverbial particles is present, it is that which provides the reduplicative base, as in (3Ib) and (32b). In this context, reduplication of the stem itself is ungrammatical, as in (3IC) and (32c). 
(3I) a. $\mathrm{Pa}=\mathrm{ka} \quad$ o $\approx$ ose.

2s.IRR $=$ NEG $\quad \mathrm{RD} \approx$ paddle

'Don't paddle.'

b. $\mathrm{Pa}=\mathrm{ka} \quad$ maa $\approx$ malaose.

2S.IRR $=$ NEG $\quad \mathrm{RD} \approx \mathrm{a}$.little paddle

'Don't paddle for a little while.'

c. $*$ pa $=\mathrm{ka}$ mala $\quad \approx$ ose

2S.IRR=NEG a.little $\mathrm{RD} \approx$ paddle

(32) a. Ta $\quad \mathbf{0} \approx 0$ ese $=$ e-la $=$ to.

PRF.3SGS RD $\approx$ paddle $=I P F V-3$ SGS $=$ PRS

'He is paddling.'

b. Ta $\quad$ boo $\approx$ boo ose $=e-l a=t o$.

PRF.3SGS RD $\approx$ previously paddle $=$ IPFV -3 SGS $=$ PRS

'He has already been paddling.'

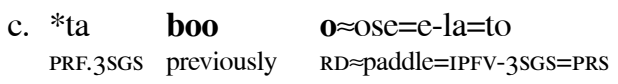

Inflectional reduplication is therefore associated with a particular syntactic position in the verb complex, rather than a morphological position relating to the verb stem, and is therefore a clitic.

I propose that the symbol " $\approx$ " be used to indicate that a reduplicant is a clitic, corresponding to the conventional use of " " to represent affixed reduplicant concatenation, in parallel with the conventional use of "=" to represent non-reduplicant clitic concatenation corresponding to "-" for affixes.

3.3 FUNCTIONS OF INFLECTIONAL REDUPLICATION. Inflectional reduplication is confined to exactly three morphosyntactic environments, occurring in:

(33) a. all clauses displaying the negation marker $k a$ on a preverbal TAM/SBJ particle, as in (3I);

b. all clauses displaying the imperfective marker $e^{-}$, as in (32); and

c. some clauses displaying the imperfective marker $s a$-, as in (5c) above.

4. FUNCTIONAL CHARACTERISTICS OF THE TWO IMPERFECTIVE MARKERS AND REDUPLICATION. The precise aspectual reading of each individual clause with imperfective aspect marking depends on a range of factors, including: which imperfective marker is present; whether or not reduplication is present; the aspectual semantics of the verb itself; and the presence of any other modal, aspectual, or tense markers. This section teases apart these factors in an effort to determine the aspectual function of each of the two imperfective markers and the functional role of reduplication in the imperfective construction.

To identify the semantic effects of each combination of imperfective marker and reduplication, each has been investigated in conjunction with verbs with a range of diverse aspectual semantics, and with a set of combinations of additional modal, aspectual, and tense combinations. The verbs investigated, with their aspectual semantic type, are: 


$\begin{array}{lll}\text { (34) geesi } & \text { 'be big' } & \text { (stative) } \\ \text { beesu } & \text { 'be hungry' } & \text { (experiencer) } \\ \text { peko } & \text { 'like' } & \text { (psych) } \\ \text { tegese } & \text { 'stand' } & \text { (postural) } \\ \text { sobii } & \text { 'walk' } & \text { (activity) } \\ \text { paru } & \text { 'build' } & \text { (accomplishment) } \\ \text { kaisi } & \text { 'take, get' } & \text { (achievement) }\end{array}$

Imperfective aspect was investigated in conjunction with the following combinations of other modal, aspectual, and tense markers:

(35) irrealis

irrealis plus perfect aspect

irrealis plus definite irrealis

realis

realis plus perfect aspect

realis plus past tense

realis plus present tense

This is not an exhaustive set of possible combinations, but is intended to provide a sufficient range to investigate the interplay of imperfective aspect with each of realis and irrealis modality, perfect aspect, and past and present tense, and to some extent their interplay with each other, along with their interaction with verbal aspectual semantics.

The semantics of each combination in (34) and (35) in clauses displaying imperfective marking are presented in tables 7-I3. Each TAM combination investigated is represented by a column in the tables. The rightmost column in each table represents the semantics identified here as common across each row. This therefore represents the aspectual semantics of each imperfective marker/reduplication combination for each verb, once the common effects of each other TAM combination represented by each column has been stripped away. For example, futurity in the IRR column may be attributed to the presence of irrealis marking and may be stripped away. Conditionality in the IRR+PRF column may be attributed to the combination of irrealis and perfect marking, and obligation in the IRR+DEFIRR column to the presence of definite irrealis marking, and so on. The residual semantics in each cell that is shared with other cells in the same row is assumed to be the semantics of the imperfective marker/reduplication combination represented by that row. An asterisk indicates that the combination of imperfective marking, reduplication, and other TAM marking represented by a particular cell is unacceptable to speakers.

\subsection{IMPERFECTIVE ASPECT WITH STATIVE, EXPERIENCER, PSYCH,} AND POSTURAL VERBS. The stative, experiencer, psych, and postural verbs investigated broadly pattern in the same way in the aspectual semantic effects of the various TAM combinations investigated here, as the findings in tables 7-IO show. On the basis of their similar patterning, the stative, experiencer, psych, and postural verbs investigated may be treated as "stative" type verbs in relation to their aspectual behavior.

For each verb of this type investigated, the imperfective marking combination of the form $s a$ - and a lack of reduplication gives a simple continuous reading, indicating that the state, experienced sensation, psychological process, or posture is ongoing. 
For combinations with reduplication the picture is more complex. $S a$ - only occurs with reduplication in realis clauses that lack overt tense marking (past or present). $E$ - only occurs with reduplication, but does not occur in tenseless realis, occurring only in irrealis, or in realis with tense marking.

The combination of $s a$ - and reduplication always gives a habitual reading with these verbs. The postural verb tegese 'stand' has a lexicalized nonliteral alternative meaning

TABLE 7. geesi 'BE BIG' (STATIVE)

\begin{tabular}{|c|c|c|c|c|c|c|c|c|}
\hline & IRR & $\mathrm{IRR}+\mathrm{PRF}$ & $\begin{array}{c}\text { IRR + } \\
\text { DEFIRR }\end{array}$ & RL & $\mathrm{RL}+\mathrm{PRF}$ & $\mathrm{RL}+\mathrm{PST}$ & $\mathrm{RL}+\mathrm{PRS}$ & \\
\hline$s a-$ & $\begin{array}{c}\text { will be } \\
\text { big }\end{array}$ & $\begin{array}{c}\text { if } \\
\text { continue to } \\
\text { be big }\end{array}$ & $\begin{array}{l}\text { must be } \\
\text { big }\end{array}$ & $\begin{array}{c}\text { when } \\
\text { were big }\end{array}$ & $*$ & $\begin{array}{l}\text { were } \\
\text { big }\end{array}$ & $\begin{array}{l}\text { are } \\
\text { big }\end{array}$ & CONT \\
\hline$s a-+\mathrm{RD}$ & $*$ & $*$ & $*$ & $\begin{array}{c}\text { are always } \\
\text { big }\end{array}$ & $\begin{array}{c}\text { are always } \\
\text { big }\end{array}$ & $*$ & $*$ & НАВ \\
\hline$e-+\mathrm{RD}$ & $\begin{array}{c}\text { will be } \\
\text { becoming } \\
\text { big }\end{array}$ & $\begin{array}{c}\text { if are } \\
\text { becoming } \\
\text { big }\end{array}$ & $\begin{array}{l}\text { must be } \\
\text { becoming } \\
\text { big }\end{array}$ & $*$ & $*$ & $\begin{array}{c}\text { were } \\
\text { becoming } \\
\text { big }\end{array}$ & $\begin{array}{c}\text { are } \\
\text { becoming } \\
\text { big }\end{array}$ & PRG INCH \\
\hline
\end{tabular}

TABLE 8. beesu 'BE HUNGRY' (EXPERIENCER)

\begin{tabular}{|c|c|c|c|c|c|c|c|c|}
\hline & IRR & $\mathrm{IRR}+\mathrm{PRF}$ & $\begin{array}{c}\text { IRR + } \\
\text { DEFIRR }\end{array}$ & RL & $\mathrm{RL}+\mathrm{PRF}$ & $\mathrm{RL}+\mathrm{PST}$ & $\mathrm{RL}+\mathrm{PRS}$ & \\
\hline$s a-$ & $\begin{array}{l}\text { will be } \\
\text { hungry }\end{array}$ & $\begin{array}{c}\text { if are } \\
\text { hungry }\end{array}$ & $\begin{array}{l}\text { must be } \\
\text { hungry }\end{array}$ & $\begin{array}{c}\text { when were } \\
\text { hungry }\end{array}$ & $*$ & $\begin{array}{c}\text { were } \\
\text { hungry }\end{array}$ & $\begin{array}{c}\text { are } \\
\text { hungry }\end{array}$ & CONT \\
\hline$s a-+\mathrm{RD}$ & $*$ & $*$ & $*$ & $\begin{array}{l}\text { are always } \\
\text { hungry }\end{array}$ & $\begin{array}{c}\text { are always } \\
\text { hungry }\end{array}$ & $*$ & $*$ & HAB \\
\hline$e-+\mathrm{RD}$ & $\begin{array}{c}\text { will } \\
\text { always be } \\
\text { hungry }\end{array}$ & $\begin{array}{c}\text { if are } \\
\text { becoming } \\
\text { hungry }\end{array}$ & $\begin{array}{l}\text { must be } \\
\text { becoming } \\
\text { hungry }\end{array}$ & $*$ & $*$ & $\begin{array}{c}\text { were } \\
\text { becoming } \\
\text { hungry }\end{array}$ & $\begin{array}{c}\text { are } \\
\text { hungry }\end{array}$ & $\begin{array}{l}\text { HAB/ } \\
\text { PRG INCH/ } \\
\text { CONT }\end{array}$ \\
\hline
\end{tabular}

TABLE 9. peko 'LIKE' (PSYCH)

\begin{tabular}{|c|c|c|c|c|c|c|c|c|}
\hline & IRR & $\mathrm{IRR}+\mathrm{PRF}$ & $\begin{array}{c}\text { IRR + } \\
\text { DEFIRR }\end{array}$ & RL & $\mathrm{RL}+\mathrm{PRF}$ & $\mathrm{RL}+\mathrm{PST}$ & $\mathrm{RL}+\mathrm{PRS}$ & \\
\hline$s a-$ & $\begin{array}{l}\text { will } \\
\text { like }\end{array}$ & $\begin{array}{l}\text { if will like } \\
\text { (don't now) }\end{array}$ & $\begin{array}{l}\text { must } \\
\text { always } \\
\text { like }\end{array}$ & $\begin{array}{l}\text { when } \\
\text { liked }\end{array}$ & $*$ & $\begin{array}{l}\text { used to } \\
\text { like }\end{array}$ & like & CONT \\
\hline$s a-+\mathrm{RD}$ & $*$ & $*$ & $*$ & $\begin{array}{l}\text { always } \\
\text { like }\end{array}$ & $\begin{array}{l}\text { always } \\
\text { like }\end{array}$ & $*$ & $*$ & НАВ \\
\hline$e-+\mathrm{RD}$ & $\begin{array}{l}\text { will } \\
\text { always } \\
\text { like }\end{array}$ & $\begin{array}{l}\text { if are } \\
\text { starting } \\
\text { to like }\end{array}$ & $\begin{array}{l}\text { must be } \\
\text { starting } \\
\text { to like }\end{array}$ & * & $*$ & $\begin{array}{c}\text { were } \\
\text { starting } \\
\text { to like }\end{array}$ & $\begin{array}{c}\text { are } \\
\text { starting } \\
\text { to like }\end{array}$ & $\begin{array}{l}\mathrm{HAB} / \\
\text { PRG INCH }\end{array}$ \\
\hline
\end{tabular}

TABLE 10. tegese 'STAND' (POSTURAL)

\begin{tabular}{|c|c|c|c|c|c|c|c|c|}
\hline & IRR & $\mathrm{IRR}+\mathrm{PRF}$ & $\begin{array}{c}\text { IRR + } \\
\text { DEFIRR }\end{array}$ & RL & $\mathrm{RL}+\mathrm{PRF}$ & $\mathrm{RL}+\mathrm{PST}$ & $R L+P R S$ & \\
\hline$s a-$ & $\begin{array}{l}\text { will be } \\
\text { standing }\end{array}$ & $\begin{array}{c}\text { if are } \\
\text { standing }\end{array}$ & $\begin{array}{l}\text { must be } \\
\text { standing }\end{array}$ & $\begin{array}{l}\text { when were } \\
\text { standing }\end{array}$ & * & $\begin{array}{c}\text { were } \\
\text { standing }\end{array}$ & $\begin{array}{c}\text { are } \\
\text { standing }\end{array}$ & CONT \\
\hline$s a-+\mathrm{RD}$ & $\begin{array}{l}\text { (will be } \\
\text { starting to } \\
\text { leave) }\end{array}$ & $*$ & $*$ & $\begin{array}{c}\text { (are } \\
\text { starting } \\
\text { to leave) }\end{array}$ & $\begin{array}{c}\text { are } \\
\text { always } \\
\text { standing }\end{array}$ & $*$ & $*$ & НАВ \\
\hline$e-+\mathrm{RD}$ & $\begin{array}{l}\text { (will be } \\
\text { starting to } \\
\text { leave) }\end{array}$ & $\begin{array}{c}\text { if are } \\
\text { starting to } \\
\text { stand }\end{array}$ & $\begin{array}{l}\text { (must be } \\
\text { starting to } \\
\text { leave) }\end{array}$ & $*$ & $*$ & $\begin{array}{c}\text { were } \\
\text { starting } \\
\text { to stand }\end{array}$ & $\begin{array}{c}\text { are } \\
\text { starting to } \\
\text { stand }\end{array}$ & PRG INCH \\
\hline
\end{tabular}


'start to leave' that emerges in certain TAM combinations, the details of which have not been fully investigated at this stage. This is semantically distinct from its literal postural meaning, and instances in table Io involving the nonliteral meaning have been parenthesized. When this reading emerges in clauses with tegese, sa-, and reduplication, the reading appears not to represent habitual aspect. Aside from this, the combination of $s a$ - and reduplication always expresses habitual aspect with stative type verbs, and this appears to be the basic semantic effect of this combination with verbs of this type.

The combination of $e$ - and reduplication generally gives a progressive inchoative reading, indicating that a process of change is under way in which the state, experience, psychological process, or posture is developing or intensifying. Aside from the nonliteral meaning of tegese, there are two exceptions to this generalization. In one, the combination gives a habitual reading to experiencer and psych verbs in irrealis clauses that lack other marking such as perfect or definite irrealis. 5 The other exception is the apparent simple continuous reading for the combination of $e$ - and reduplication with realis and present marking on the verb beesu. This last apparent anomaly requires further investigation.

In summary, with stative type verbs the imperfective marking and reduplication combinations have the following aspectual effects:

(36) a. $s a$-with no reduplication: continuous aspect;

b. $s a$ - with reduplication: habitual aspect;

c. $e$-with reduplication: progressive inchoative aspect, habitual aspect (experiencer/psych verbs in some TAM contexts), continuous aspect (in one TAM context with one verb).

\subsection{IMPERFECTIVE ASPECT WITH ACTIVITY, ACCOMPLISHMENT,} AND ACHIEVEMENT VERBS. The activity, accomplishment, and achievement verbs investigated also broadly pattern alike in their aspectual semantics under the effect of the various TAM combinations investigated here, as shown in tables I I-I3.

On the basis of their similar patterning, the activity, accomplishment, and achievement verbs investigated may be treated as "active" type verbs in relation to their aspectual behavior, although there are some differences on the basis of telicity.

For each active type verb investigated, the imperfective marking combination of the form $s a$ - and a lack of reduplication gives a persistive reading. This indicates that the event occurs as a continuation of a prior occurrence of that same event.

Just as with stative type verbs, with active types in imperfective combinations with reduplication the picture is also complex. As with stative types, $s a$-with reduplication is largely confined to realis clauses lacking overt tense marking, and $e$ - only occurs with reduplication in irrealis clauses or in realis clauses with tense marking.

However, with two of the three active type verbs investigated, $s a$ - occurs with reduplication in one other context investigated: irrealis without perfect or definite irrealis. This is the only TAM context investigated where reduplication can occur with either $s a$ - or $e$-, with differing readings. In this context, $s a$ - with reduplication has several additional semantic elements, which are shared by both verbs. This combination in this context indi-

5. This shared behavior may indicate that verbs such as beesu 'be hungry' and peko 'like' in fact have shared experiencer semantics as expressions of physical or psychological experience. 
cates that the event will begin to be carried out (thus akin to inceptive aspect), but that only a subset of all ultimate subjects will initially participate. Say a journey or the building of a structure is planned. This process will begin. Some of those who will be involved will set off on foot first, or begin work before the others. The others will follow later or join in later in the construction. It is not clear at this stage why the combination of $s a$ - and reduplication only in otherwise unmarked irrealis should prompt this reading, and why it is confined to these two verbs out of those investigated. The distribution suggests that the reading is confined to active type verbs, and within that, only to verbs expressing inherently durative events (activity and accomplishment verbs) as opposed to those expressing nondurative events (achievement verbs). Beyond those observations, this issue requires further investigation.

Aside from the occurrence of $s a$ - and reduplication in otherwise unmarked irrealis, which have been parenthesized in tables I I and I2, $s a$ - with reduplication is confined to tenseless realis, as with stative type verbs. And as with stative types, this combination with

TABLE 11. sobii 'WALK' (ACTIVITY)

\begin{tabular}{|c|c|c|c|c|c|c|c|c|}
\hline & IRR & $\mathrm{IRR}+\mathrm{PRF}$ & $\begin{array}{c}\text { IRR + } \\
\text { DEFIRR }\end{array}$ & RL & $R L+P R F$ & $\mathrm{RL}+\mathrm{PST}$ & $\mathrm{RL}+\mathrm{PRS}$ & \\
\hline$s a-$ & $\begin{array}{c}\text { will } \\
\text { continue } \\
\text { walking }\end{array}$ & $\begin{array}{c}\text { if } \\
\text { continue } \\
\text { walking }\end{array}$ & $\begin{array}{c}\text { must } \\
\text { continue } \\
\text { walking }\end{array}$ & $*$ & $*$ & $\begin{array}{c}\text { were } \\
\text { continuing } \\
\text { to walk }\end{array}$ & $\begin{array}{c}\text { are } \\
\text { continuing } \\
\text { to walk }\end{array}$ & PERSIST \\
\hline$s a-+\mathrm{RD}$ & $\begin{array}{c}\text { (some will } \\
\text { walk } \\
\text { ahead) }\end{array}$ & $*$ & $*$ & $\begin{array}{c}\text { are always } \\
\text { walking }\end{array}$ & $\begin{array}{c}\text { are always } \\
\text { walking }\end{array}$ & $*$ & $*$ & HAB \\
\hline$e-+\mathrm{RD}$ & $\begin{array}{l}\text { will be } \\
\text { walking }\end{array}$ & $\begin{array}{l}\text { if are walk- } \\
\text { ing }\end{array}$ & $\begin{array}{c}\text { must start } \\
\text { walking }\end{array}$ & $*$ & * & $\begin{array}{c}\text { were } \\
\text { walking }\end{array}$ & $\begin{array}{c}\text { are } \\
\text { walking }\end{array}$ & $\begin{array}{l}\text { PRG/ } \\
\text { PRG } \\
\text { INCEPT }\end{array}$ \\
\hline
\end{tabular}

TABLE 12. paru 'BUILD' (ACCOMPLISHMENT)

\begin{tabular}{|c|c|c|c|c|c|c|c|c|}
\hline & IRR & $\mathrm{IRR}+\mathrm{PRF}$ & $\begin{array}{c}\text { IRR + } \\
\text { DEFIRR }\end{array}$ & $\mathrm{RL}$ & $R L+P R F$ & $\mathrm{RL}+\mathrm{PST}$ & $\mathrm{RL}+\mathrm{PRS}$ & \\
\hline$s a-$ & $\begin{array}{c}\text { will } \\
\text { continue } \\
\text { building }\end{array}$ & $\begin{array}{c}\text { if } \\
\text { continue } \\
\text { building }\end{array}$ & $\begin{array}{c}\text { must } \\
\text { continue } \\
\text { building }\end{array}$ & $*$ & $*$ & $\begin{array}{c}\text { were } \\
\text { continuing } \\
\text { to build }\end{array}$ & $\begin{array}{c}\text { are } \\
\text { continuing } \\
\text { to build }\end{array}$ & PERSIST \\
\hline$s a-+\mathrm{RD}$ & $\begin{array}{l}\text { (some will } \\
\text { start build- } \\
\text { ing) }\end{array}$ & $*$ & $*$ & $\begin{array}{c}\text { are } \\
\text { building }\end{array}$ & $\begin{array}{c}\text { are always } \\
\text { building }\end{array}$ & $*$ & $*$ & PRG/ HAB \\
\hline$e-+\mathrm{RD}$ & $\begin{array}{l}\text { will be } \\
\text { building }\end{array}$ & $\begin{array}{c}\text { if are } \\
\text { building }\end{array}$ & $\begin{array}{l}\text { must } \\
\text { always be } \\
\text { building }\end{array}$ & $*$ & $*$ & $\begin{array}{c}\text { were } \\
\text { building }\end{array}$ & $\begin{array}{l}\text { are start- } \\
\text { ing to build }\end{array}$ & $\begin{array}{l}\text { PRG/ } \\
\text { PRG } \\
\text { INCEPT }\end{array}$ \\
\hline
\end{tabular}

TABLE 13. kaisi 'TAKE, GET' (ACHIEVEMENT)

\begin{tabular}{|c|c|c|c|c|c|c|c|c|}
\hline & IRR & $\mathrm{IRR}+\mathrm{PRF}$ & $\begin{array}{c}\text { IRR + } \\
\text { DEFIRR }\end{array}$ & RL & $\mathrm{RL}+\mathrm{PRF}$ & $\mathrm{RL}+\mathrm{PST}$ & $\mathrm{RL}+\mathrm{PRS}$ & \\
\hline$s a-$ & $\begin{array}{c}\text { will } \\
\text { continue } \\
\text { getting }\end{array}$ & $\begin{array}{c}\text { if } \\
\text { continue } \\
\text { getting }\end{array}$ & $\begin{array}{c}\text { must } \\
\text { continue } \\
\text { getting }\end{array}$ & $*$ & $*$ & $\begin{array}{c}\text { were } \\
\text { continuing } \\
\text { to get }\end{array}$ & $\begin{array}{c}\text { are } \\
\text { continuing } \\
\text { to get }\end{array}$ & PERSIST \\
\hline$s a-+\mathrm{RD}$ & $*$ & $*$ & $*$ & $\begin{array}{c}\text { are } \\
\text { getting }\end{array}$ & $\begin{array}{l}\text { are always } \\
\text { getting }\end{array}$ & $*$ & $*$ & $\begin{array}{l}\text { PRG/ } \\
\text { HAB }\end{array}$ \\
\hline$e-+\mathrm{RD}$ & $\begin{array}{l}\text { will be get- } \\
\text { ting }\end{array}$ & $\begin{array}{l}\text { if are } \\
\text { getting }\end{array}$ & $\begin{array}{l}\text { must start } \\
\text { getting }\end{array}$ & $*$ & $*$ & $\begin{array}{l}\text { were } \\
\text { getting }\end{array}$ & $\begin{array}{c}\text { are } \\
\text { starting } \\
\text { to get }\end{array}$ & $\begin{array}{l}\text { PRG/ } \\
\text { PRG } \\
\text { INCEPT }\end{array}$ \\
\hline
\end{tabular}


realis and perfect aspect gives a habitual reading. However, unlike with stative types, this combination with realis but no perfect marking does not necessarily give a habitual reading. Instead, it gives a simple progressive reading for paru 'build' and kaisi 'take, get', while carrying the habitual sense with sobii 'walk'. This represents a generalization that crosscuts the stative/active type division. Being accomplishment and achievement verbs, paru and kaisi express telic events, while sobii, being an activity verb, expresses an atelic event. In this respect, sobii resembles the stative types, all of which express atelic events. Imperfective marking with $s a$ - and reduplication is therefore sensitive to telicity. This combination with otherwise TAM-unmarked realis gives a habitual reading with atelic verbs and a simple progressive reading with telic verbs, regardless of stative/active typing.

The combination of $e$ - and reduplication with active type verbs gives a simple progressive reading in most contexts. However, two contexts show different aspectual semantics. With the combination of irrealis and definite irrealis marking, $e$ - and reduplication have a progressive inceptive reading for sobii 'walk' and kaisi 'take, get', and a habitual reading for paru 'build'. With the combination of realis and present tense marking, $e$ - and reduplication give a progressive inceptive reading for the two telic verbs paru 'build' and kaisi 'take, get' (but a simple progressive reading for sobii 'walk').

In summary, with active type verbs the imperfective marking and reduplication combinations have the following aspectual effects:

(37) a. $s a$ - with no reduplication: persistive aspect;

b. $s a$ - with reduplication: habitual aspect, progressive aspect

(telic verbs in otherwise unmarked realis);

c. $e$ - with reduplication: progressive aspect, progressive inceptive aspect (in some TAM contexts).

\subsection{SUMMARY OF IMPERFECTIVE FORM AND REDUPLICATION}

DISTRIBUTION. Conflating the findings presented in (36) and (37), the aspectual functional characteristics of each combination of imperfective marker and reduplication may be summarized as follows:

(38) a. $s a$ - with no reduplication: continuous aspect (stative verbs), persistive aspect (active verbs);

b. $s a$ - with reduplication: habitual aspect, progressive aspect (telic verbs in otherwise unmarked realis);

c. $e$ - with reduplication: progressive inchoative/inceptive aspect, progressive aspect (active verbs in most TAM contexts), habitual aspect (experiencer/psych verbs in some TAM contexts).

These findings allow the attempt to tease apart the aspectual functional characteristics of each imperfective marker and of reduplication presented in 4.4 and 4.5 .

\subsection{IMPERFECTIVE FUNCTIONAL CHARACTERISTICS OF REDUPLI-}

CATION. The distribution of reduplication shown in (38) is summarized in table I4. Broadly speaking, (38) and table I4 reveal that active type verbs require reduplication to encode simple progressive aspect (along with most other subtypes of imperfective), while stative verbs do not require reduplication to encode simple continuous aspect. This 
means that in terms of reduplication, simple continuous is the unmarked aspectual status for stative verbs, but a marked aspectual status for active verbs. The marked and unmarked aspectual status of each overall verb type is shown in table I5.

\subsection{FUNCTIONAL CHARACTERISTICS OF IMPERFECTIVE MARKER}

CHOICE. The markers $s a$ - and $e$ - both mark imperfective aspect. The findings summarized in (38) suggest no generalization about distinct functional characteristics of each marker: each occurs with all subtypes of imperfective represented in (38), other than persistive. However, the key to interpreting the distribution of the two markers lies in the superficially anomalous occurrence of $s a$ - with reduplication in realis clauses that lack overt tense marking. Once that is taken into account, two observations are possible.

$E$ - does not occur in clauses with unmarked modal and tense status. As discussed in 2.I, realis is the unmarked and default modal status. While all finite clauses in Torau have some modal status, they have no status involving tense unless tense is overtly marked (see 2.3 and 2.6). This means that in the absence of overt past or present tense marking, the event expressed by a realis clause is located in time on the basis of temporal adverbs, or failing that, discourse context, and not by means of the grammatical feature tense. Similarly, the event expressed by an irrealis clause is located in time (future versus past or present hypothetical, counterfactual, habitual, etc.) on the basis of temporal adverbs or discourse context, and not by tense. The imperfective marker $e$ - may only occur in clauses with irrealis modality (i.e., marked modality) or with overt tense marking (i.e., marked tense). It cannot occur in realis clauses with no tense marking (i.e., unmarked modality and tense). This means that regardless of the resulting aspectual semantics (which emerges from the interplay of imperfective marking, reduplication, and other TAM categories present), $e$ - marks imperfective aspect only in marked modal or tense contexts. This explains the striking and superficially anomalous phenomenon of $s a$ - occurring in place of $e$ - with reduplication in clauses with realis marking and no overt tense.

In addition, $e$ - only occurs in clauses also displaying inflectional reduplication. As discussed in 4.4, reduplication occurs with marked subtypes of imperfective, and not with unmarked subtypes (depending on the aspectual semantics of the verb). $E$ - therefore only occurs with marked subtypes of imperfective aspect.

\section{TABLE 14. ASPECTUAL FUNCTIONAL DISTRIBUTION OF REDUPLICATION IN IMPERFECTIVE ASPECT}

NO REDUPLICATION REDUPLICATION continuous aspect (stative verbs); persistive aspect (active verbs) habitual aspect; progressive inchoative/inceptive aspect; progressive aspect (active verbs)

TABLE 15. MARKED AND UNMARKED

\section{REDUPLICATIVE ASPECTUAL STATUS BY VERB TYPE}

$\begin{array}{lll} & \text { UNMARKED } & \text { MARKED } \\ \text { STATIVE TYPE VERBS } & \text { simple continuous } & \text { all other imperfective subtypes } \\ \text { ACTIVE TYPE VERBS } & \text { persistive } & \begin{array}{l}\text { all other imperfective subtypes } \\ \text { including simple progressive }\end{array}\end{array}$


In summary, $e$ - occurs in clauses with both a marked modal or tense status and a marked subtype of imperfective aspect. In contrast, $s a$ - occurs in clauses that are unmarked either in modal and tense status or in subtype of imperfective aspect. $\mathrm{Sa}$ - can therefore be seen to be the default imperfective marker, with $e$ - occurring in specific marked contexts. This is summarized in table I6.

\section{TABLE 16. FUNCTIONAL DISTRIBUTION OF IMPERFECTIVE MARKERS}

\begin{tabular}{lll} 
& MODALITY AND TENSE & SUBTYPE OF IMPERFECTIVE \\
$e-$ & marked & marked \\
$s a-$ & marked & unmarked \\
\cline { 2 - 3 } & unmarked & marked
\end{tabular}

5. CONCLUSION. Imperfective aspect is marked in Torau using a combination of imperfective markers and reduplication. The precise aspectual semantics of clauses bearing imperfective marking varies widely. It is determined by a highly complex interaction of interdependent factors, including choice of one of the two imperfective markers, the presence or absence of reduplication, the aspectual semantics of the verb itself, and the presence or absence of other markers of aspect, modality, and tense.

On the basis of their aspectual characteristics in the imperfective, Torau verbs pattern broadly into two groups: a stative type, including stative, experiencer, psych, and postural verbs; and an active type, including activity, accomplishment, and achievement verbs. While most relevant phenomena pattern on that basis, one set of functional distinctions patterns on the basis of the telicity of the verb, with atelic activity verbs patterning with the stative type, in contrast with telic accomplishment and achievement verbs, which pattern separately.

With stative types, the simple continuous subtype of imperfective aspect is unmarked, and other types, including progressive inchoative/inceptive and habitual aspect, are marked. With active types, all subtypes of imperfective including simple progressive are marked, while persistive aspect is unmarked.

Reduplication functions to encode imperfective aspect of a marked subtype, dependent on the aspectual semantics of the verb itself.

The imperfective marker $e$ - encodes marked subtypes of imperfective (depending on the semantics of the verb) in clauses with marked modal or tense status (irrealis modality, or overtly marked past or present tense). The imperfective marker $s a$ - is the default, occurring in clauses with either unmarked modality and tense (i.e., all realis clauses lacking overt tense marking), or expressing an unmarked imperfective subtype (simple continuous with stative type verbs, persistive aspect with active types).

The analysis presented here demonstrates the interdependence of aspectual, modal, and tense features in general, and shows that the functional characteristics of individual features are determined to a substantial extent by the interaction of multiple features. In order to understand the functional characteristics of any one category of aspect, modality, or tense, it is necessary to examine a range of such features and categories in conjunction with each other. 


\section{REFERENCES}

Anderson, Stephen R. 2005. Aspects of the theory of clitics. Oxford: Oxford University Press.

Inkelas, Sharon. I990. Prosodic constituency in the lexicon. New York: Garland.

Palmer, Bill. To appear. Possessive morphology as argument-indexing in Northwest Solomonic. Linguistics.

Ross, Malcolm D. I982. The development of the verb phrase in the Oceanic languages of the Bougainville region. In Papers from the Third International Conference on Austronesian Linguistics, vol. I, Currents in Oceanic, ed. by Amran Halim, Lois Carrington, and Stephen. A. Wurm, I-57. Canberra: Pacific Linguistics.

. 1988. Proto Oceanic and the Austronesian languages of western Melanesia. Canberra: Pacific Linguistics. 
Copyright of Oceanic Linguistics is the property of University of Hawaii Press and its content may not be copied or emailed to multiple sites or posted to a listserv without the copyright holder's express written permission. However, users may print, download, or email articles for individual use. 